\title{
Perception, understanding, and action: attitudes of climate change in the Hungarian population
}

\author{
Ferenc JANKÓ ${ }^{1}$, Laura BERTALAN ${ }^{1}$, Mónika HOSCHEK ${ }^{1}$, Karolina KOMORNOKI ${ }^{2}$, \\ Nikoletta NÉMETH ${ }^{1}$ and Judit PAPP-VANCSÓ ${ }^{3}$
}

\begin{abstract}
This study is based on a non-representative, national level survey sample whose main purpose is to interpret the general population's understanding of climate change. The study also provides an examination of correlations between climate change concerns and the taking of individual action as well as the relationship between pro-environmental thinking and climate change scepticism. Our results show a moderate correlation between the general population's concerns and the professional views on the subject, known in the literature as the New Environmental Paradigm scale and Scepticism scale, but a significantly weaker correlation when it comes to taking action against climate change. Factors relating to the respondents, such as residence settlement type, education level, gender, age, personal and social values, or casual attributions in relation to climate change heavily influence this weaker correlation. Most respondents assessed climate change as a current (urgent), but geographically remote phenomenon. This is a clear indication of problems associated with cognitive conceptualization and the localization of climate change in communication. The target audience must be taken into account when designing climate change communications because interpretations of climate change can vary widely and cover a broad range attitudes ranging from concern about to issue all the way to climate change scepticism. This also applies to views concerning responsibility for climate change with some believing it is a political responsibility and others believing it is a scientific responsibility.
\end{abstract}

Keywords: climate change, perception, responsibility, climate adaptation, climate change denial, Hungary

\section{Introduction}

Public understanding of climate change in the context of the surrounding public-political discussions has become an essential subject of social science research papers. Beyond the territory of physical science, several societal aspects of climate change have also been brought into the focus of research, thus, similar activities in the topic have begun in Hungary with varying intensity and scope from the mid' 2000s. While extended research on Hungarian climate change futures (e.g. BARTHOLY, J. et al. 2014) forms the context, recent scholarship focused on the knowledge of climate change in society (Mosoni-FrIED, J. et al. 2007; TÁRKI 2007; SZIRMAI, V. et al. 2008; BARANYAI, N. and VARJú, V. 2015), on adaptation issues and impact on society (SALAmin, G. et al. 2011; BАJMóczy, P. et al. 2012; MesterházY, I. et al. 2014; Antal, Z.L. 2015; Bobvos, J. et al. 2017; FArKas, J.Zs. et al. 2017; KAJNer, P. et al. 2017; KirÁLy, G. et al. 2017), or on climate discourses and controversies (JANKó, F. et al. 2010, 2011; BereczKI, B.H. 2012; Kőszegi, M. et al. 2015). However, we do not know enough about climate and climate change. As Hulme, M. (2008) argues, geography should unfold

\footnotetext{
${ }^{1}$ University of Sopron, Alexandre Lámfalussy Faculty of Economics, H- 9400 Sopron, Erzsébet u. 9. E-mails: frk.geo@ gmail.com, bertalan.laura@uni-sopron.hu, hoschek.monika@uni-sopron.hu,nemeth.nikoletta@uni-sopron.hu

${ }^{2}$ Elisabeth Educational Hospital of Sopron, H-9400 Sopron, Győri u. 15. E-mail: komornoki.karolina@upcmail.hu

${ }^{3}$ Gyula Roth Technical School of Forestry and Wood Industry, H-9400 Sopron, Szent György u. 9. E-mail: vancsojudit@gmail.com
} 
the social meanings of climate and the effect of geographical scales i.e. localization in the understanding of climate change. Our study aims to develop our knowledge in this direction.

The following questions guided our investigation: What kind of relationships are there between the concerns about and experiences of climate change and green actions? Which factors tend to influence people's readiness to act? Is there any correlation between the place of residence and the experiences and evaluation of climate change? What kind of role does the proximity or, conversely, the remoteness of the phenomenon in terms of geography and time play in the perception of the problem? How vital is the topic of climate change? Who or what is the primary cause of the problem and, in the opinion of the people questioned in our survey, whose responsibility is to find the solution? In line with the questions we raised, we assumed that concern and experience are strongly correlated to actions; moreover, we assumed that the level of concern is inversely proportionate to the intensity of actions ('it's all the same anyhow' attitude) (SEARLE, K. and Gow, K. 2010). Additionally, we hypothesized that opinions on the topic will most probably be divided even though respondents believe climate change to be a significant problem, and that the issue of climate change will be identified as something remote from Hungary from a geographical point of view (contrary to the scientific forecasts).

\section{Literature review}

A wide range of various social sciences is currently interested in climate change research. From our study's point of view, the analyses focusing on the questions of perception, the formation of attitudes and communication have relevance and determine public action, inaction and engagement. Therefore, we emphasize the fields of sociology and psychology (Lorenzoni, I. and Pidgeon, N.F. 2006; Formádi, K. 2013), working real close to geography here. In addition, as the result of successful integrating efforts of Anglo-
Saxon social geography, an independent field of research is slowly shaping around the social understanding of climate change (Demeritt, D. 2001; Hulme, M. 2008, 2009), however, this approach is still marginal in Hungary (JANKó, F. et al. 2010). In the USA, a whole series of studies focus on the opposing views of climate change that exists between the high level of consensus within the scientific community and the balanced or otherwise polarized opinions of the civil society, or of those presented in the media (FARMER, G.T. and Coок, J. 2013). The related problems and the reasons for such contradictions are identified, on the one hand, as the cognitive bias towards climate change (WHITMARSH, L. 2011; Stoknes, P.E. 2014), the limits of perception and visibility (Hulme, M. 2014), the processing of risks and direct concern, and the differences between personal values (Weber, E.U. and Stern, P.C. 2011; Donner, S.D. 2011). On the other hand, the complex and politicized nature of the topic and the successful operation of well-organized, climate change sceptic 'denial machine' are emphasized (DunlaP, R.E. and MCCRIGHT, A.M. 2011; FArmer, G.T. and Сook, J. 2013).

Upon the examination of five factors (extreme weather events, public access to accurate scientific information, media coverage, elite (political) cues and the movement and countermovement advocacy), BRULLE, R.J. et al. (2012) established that changes in concerns about climate change are primarily influenced by elite political cues and related economic factors as well as by the media. Not surprisingly, climate scepticism and the relations thereof to values and experiences are also in the focus of several studies (Whitmarsh, L. 2011).

The research papers that concentrate on the relationship between personal experience and the reality of climate change clearly indicate the profundity of the experience and perception theme. The studies of Egan, P.J. and Mullin, M. (2012), Akerlof, K. et al. (2013), Hamilton, L.C. and Stampone, M.D. (2013) compare the experiences of respondents to actual climate data, while Myers, T.A. et al. (2013) demonstrate both learning-by-expe- 
rience (where personal exposure leads to an increasing belief in climate change) and motivated reasoning (where the prior, firm conviction manipulates perception and experience). Several studies emphasize the correlation between personal experience and motivation to act (LoRENZONI, I. and Pidgeon, N.F. 2006; BroomelL, S.B. et al. 2015), while socialgeographic approaches also underscore the role of locality and temporality in this respect (Brace, C. and Georghegan, H. 2010).

Communication must also be emphasized, as various governmental and non-governmental campaigns aspire to influence the engagement towards and actions related to climate change. The core question of communication is how can attention be raised authentically by transmitting a consistent, valid, and true interpretation of climate change. (We should only think about the catastrophe-focused language of our colonial attitudes related to developing countries in the communication panels.) In addition, how can we, through the internet primarily, give precise information and instructions to people concerning the complex problem of climate change (Manzo, K. 2010, 2012; Moser, S.C. 2010; Nerlich, B. et al. 2010; SCHÄFER, M.S. 2012; STOKNes, P.E. 2014; Jankó, F. 2015).

\section{Methodology}

Our survey took place between February 2013 and October 2015. The questionnaires were distributed in hard copies and electronic form via e-mail using the snowball sampling method; as a result, we attained a non-representative 'convenience' sample of the national coverage comprising 545 respondents. Of the respondents, 58 per cent was female, while in the age structure, young adults and persons of tertiary-level education were overrepresented (the questionnaire targeted the 14-year-old and above age group) compared to the Hungarian population. Due to the geographic origin points of the snowball, the majority of respondents were residents of Western Hungary; however, the sample represented all counties to a greater or lesser extent. Resident distribution according to settlement size turned out to be statistically adequate as Budapest represented a 16.9 per cent share and the distribution of further population clusters conforms to the national data. Otherwise, due mainly to sampling through the internet, families with kids, households with above average net incomes, persons of tertiary-level education (nearly 68\%, while national data is $15 \%$ ) and, thereby, people belonging to labour market groups requiring higher education levels were overrepresented in the sample. Hence, our questionnaire is unsuitable for describing the general approach of the entire country concerning environmental awareness, but it is satisfactory for the examination of correlations between the factors mentioned in the title.

The questionnaire was divided into six parts. Nine questions in the introductory section focused on the personal data of the respondents (gender, age, level of education, residence, household type and income per capita, labour market position). In the second block, respondents had decided which one of seven cartoons most fits their perceived conception of climate change (Figure 1).

Some of the pictures are presented in MAnzo, K. (2012) and they analyse the geopolitical aspects of climate communication as part of a cartoon competition organized by Ken Sprague Foundation. In addition, we collected more cartoons from the internet that matched our conception. Our aim was to examine observations on climate change in the mirror of visuality, to explore which interpretations are most effective at catching the attention of respondents, and to make the questionnaire interesting for respondents. These cartoons provided a sophisticated reference to the question of the perception, and the understanding of and responsibility for climate change; we positioned them at the beginning of the questionnaire to avoid any biasing of the evaluation through upcoming questions. Cartoons represented seven different ways of interpretation, and the study enabled the testing of the correctness of these associations. 


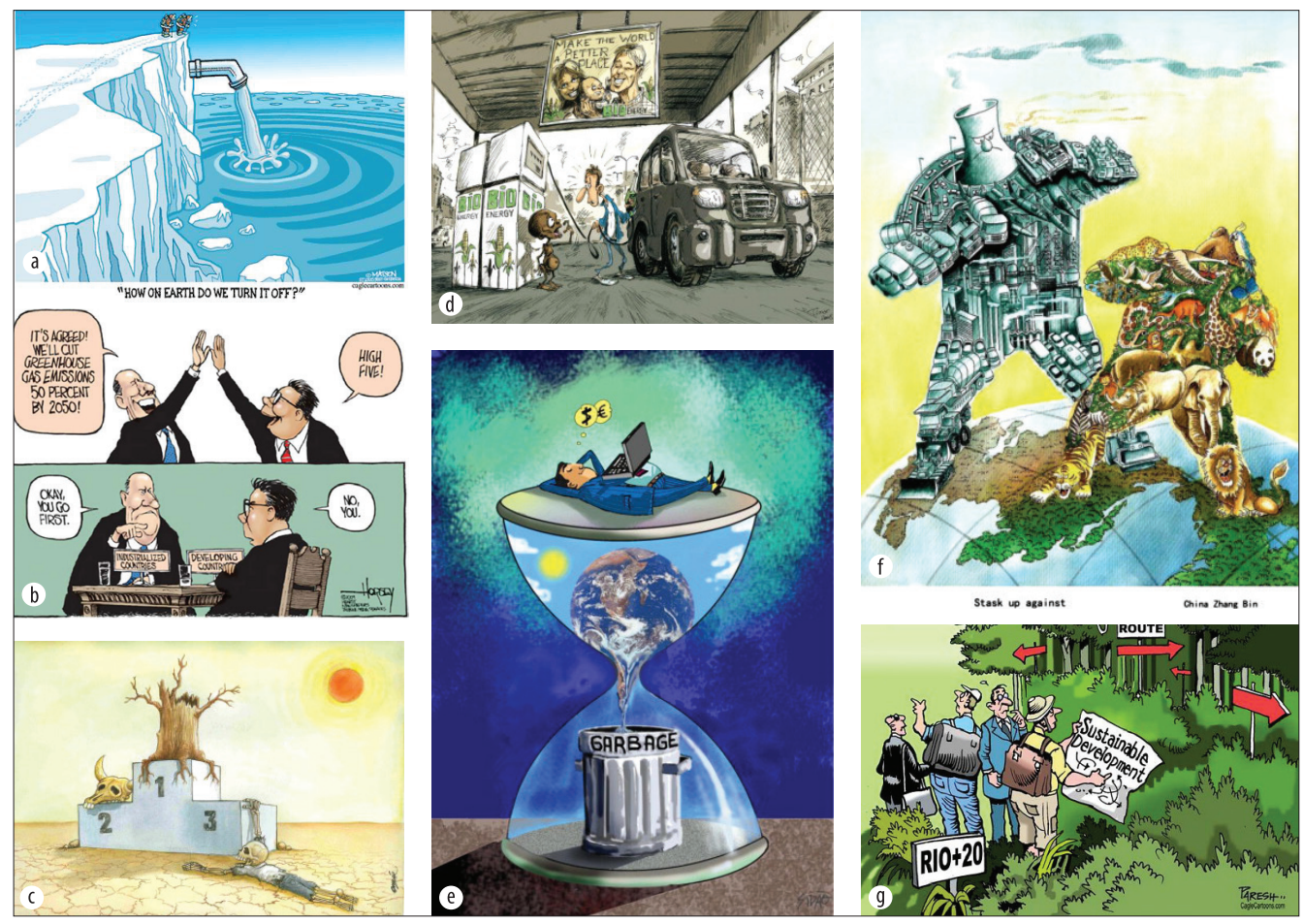

Fig. 1. Cartoons in the questionnaire. $-\mathrm{a}-\mathrm{g}=$ for explanation see the text. Sources: http://www.transitionpenwith. org.uk (a); http://www.sfchronicle.com (b); www.kenspraguefund.org (c, d, e, f); www.caglecartoons.com (g)

Climate change as a scientific problem (a), a geopolitical issue (b), a climate-catastrophe (c), a conflict of renewable energies (d), wasting (e), a conflict of nature and humanity (f) and sustainable development $(\mathrm{g})$.

The following block of questions are related to problem perception addressing its psychological, geographical and temporal factors: we asked first the respondents to prioritize global problems; after that, they had to do the same with environmental issues. By using the Likert scale, we formulated a series consisting of six questions focusing on concern (3-3 in positive and negative tone - e.g. "I am afraid of the future climate catastrophes" or "I do not care what happens to the Earth and mankind after me"), the aggregation of what provided us with a concern-index, the values of which varied on a scale between 5 and 30 (the average score was 23.23). In further questions, we tested different sectors from the aspect of their level of exposure to climate change; we also raised several questions regarding the evaluation of distance from climate change. One of these questions concentrates on the subject in terms of time: respondents had to evaluate the effects of climate change in the past, in the present, and in the future. Two questions were formulated to examine the issue of geographic distances: based on the imagined-believed climate threat, respondents were asked to rank the listed territories of different climatic conditions and continental regions.

The fourth block focuses on the issue of responsibility: through different approaches, the questions targeted the origins of climate change and the identification of those origins as well as who should be primarily responsible for finding a solution. The fifth block includes two Likert scale-based groups of 
questions, one comprising 15, the other 17 points. The former New Ecological Paradigm index ("NEP index") aimed to evaluate the level of relations between nature and humanity, i.e. pro-environmentalist thinking (on a scale ranging from 15 and 75, where the average value was 55.59), while the latter ("Scepticism index") examined the degree of scepticism (on a scale ranging from 17 and 85, where the average was 42.92). The first group of questions is known in the international scientific literature as New Ecological Paradigm (NEP) and was developed by Dunlap, R.E. et al. (2000). More precisely, Dunlap updated the scale from 1978, replacing the ecologiceconomic termini technici, which were widely known to the public in the USA back then but became obsolete in the meantime, similar to terms like steady-state economics, limits of growth, Spaceship Earth (DunlaP, R.E. and VAN LiERE, K.D. 1978 - see the lists there). The scepticism scale was developed by Whitmarsh, L. (2011) and was supplemented by Corner, A. et al. (2012). We adapted the Hungarian translation of both scales to the aims of the current research. According to international precedents, these scales are suitable to serve as the basis of development of a consistent aggregate index, though there are several issues we must acknowledge in connection with the application of the initial version of NEP (DunLAP, R.E. et al. 2000).

We dedicated the final block to actions intended to measure the level of readiness for action and activity volume. The scale included twelve partially positive and partially negative statements, from which we developed an index using the aggregation method (on a scale ranging between 12 and 60, where the average was 43.12).

\section{Results and discussion}

\section{Perception of the problem}

Among global problems, respondents ranked environmental issues as the most important (regarding the average of ranking points
[2.8], and the absolute first place as well). Here we must mention the Eurobarometer surveys that focus on the same topic and are prepared occasionally in the European Union. Within the frames of these investigations, members of the European population are requested to rank global problems. The problems identified as the most important have remained unchanged since the very beginning of these surveys (though their respective scores show a decreasing trend): these issues are poverty, lack of food, and potable water. With respect to the second and third positions, we notice a bit more motion: after 2009, climate change was forced from second into third place by the global financial crisis while international terrorism climbed into second place in 2015. The data measured in Hungary fit into this trend more or less; however, climate-related issues are less significant in general (TNS 2009, 2011, $2014,2017)$. Our methodology and the way of we formulated our questions were partially different from that of the Eurobarometer survey as we 'weighed environmental problems against other global issues': differences in results may arise partly from this fact and partly from the different sample we used.

On our scale, therefore, poverty, and lack of food and potable water reached second place in the aggregate (av. ranking points: 3.2), showing a curve sloping downwards to the right; the same applies to the problem of increasing global population (3.9). The functions of three of the listed global issues - the depletion of fossil fuel dependent energy resources (4.4), armed conflicts (4.7), and the financial crisis (5.1) - form an inverted U curve. Worldwide epidemics (5.6) and international migration (6.3) show a curve sloping downwards to the left; most probably, results would be completely different if the survey were completed today (Figure 2).

The question aimed at differentiation between environmental problems allowed the specific weighing of climate change - and came up with a surprising result. First place was divided between the issues of waste (4.4) and climate (4.9), but, on average, the highest 


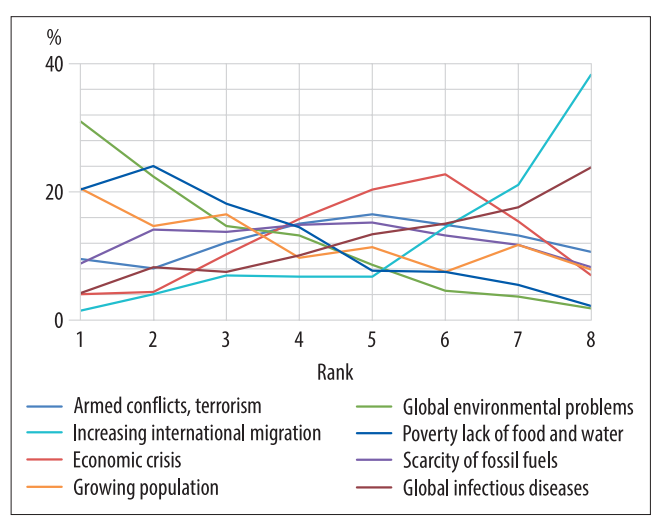

Fig. 2. Ranking of global problems

number of ranking points were awarded to water pollution (3.7). According to the visual demonstration of results, the problems of waste and water pollution show asymmetric inverted U curves (the former slightly, while the latter significantly sloping to the right); the issue of climate change draws a U curve demonstrating a strongly polarized evaluation of this topic in the sample(Figure 3$)^{4}$. Thus, on average, the issue of climate change is surpassed by deforestation and forest degradation (4.5 - inverted U curve) (in this respect, the questionnaire refers to tropical areas and the flora of taiga) by destruction of the ozone layer (4.7 - waving curve) and by the problems of soil contamination and soil destruction (4.9 - inverted U curve) as well. In this hierarchy, three issues with curves sloping to the left follow climate change: scarcity of natural resources (5.5), biodiversity loss (5.6), and acid rain (6.8 - the latter is practically excluded from environmental discourses today).

We questioned the respondents about the expectable positive and adverse effects of climate change on different sectors by using a Likert scale. With respect to agriculture, 78.5 per cent of respondents answered that the expected outcome of climate change is rather

\footnotetext{
${ }^{4}$ We should note that no similar result is presented with respect to any of the other problems measured by the survey.
}

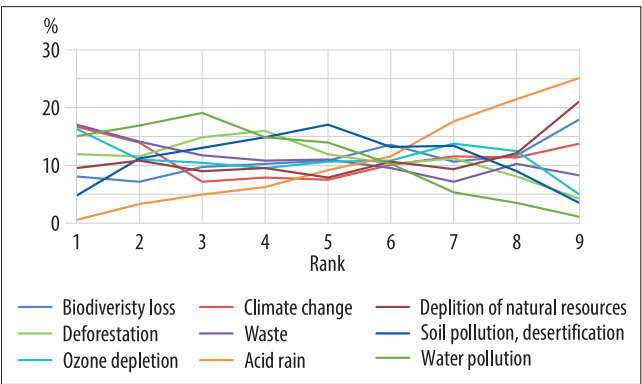

Fig. 3. Ranking of environmental problems

negative; the same answer was given by 78 per cent of respondents in connection with natural environment, and by 74 per cent in connection with the standard of living; however, regarding the industry sector, the most frequent response was "I don't know".

Several studies have already demonstrated the high level of perception of signs of climate change within the Hungarian population (TÁRKI 2007; BARANYAI, N. and VARJú, V. 2015).

We measured the experiences in and the distance of climate change in terms of time with an absolute multiple-choice question. Almost 47 per cent of respondents answered that the effects of climate change are already directly perceivable and visible, while 40 per cent chose the following among the possible answers: 'Climate change has been and is still affecting humanity and this is not expected to change in the future either.' The number of votes cast for the other options is insignificant: 9 per cent of respondents think the climate change effects will only be perceivable in the lives of their children or grandchildren; 3 per cent voted for the option of 'perceivable only in the distant future'; and 3 respondents opted for the absolute sceptical answer (there are no, and there will be no significant effects). These results correspond entirely to the statistics of TÁRKI (2007).

The answers to the questions measuring the geographical distance of the climate change problem justified our preliminary assumptions. Media influence on the ideas about climate change is clearly demonstrated in the 
case of questions approaching the problem from a climate point of view. In questions like these, respondents ranked polar regions almost unanimously in the first position (average ranking point: 2.1); islands are listed as second (3.8), while coastal countries are in third place (3.8). When applying the approach to continental regions, the first ranked territories were Australia and Oceania (3.4 - most probably because of the latter), while South and East Asia (3.8), Africa and the Middle East (4.0) were listed as second and third. Areas of continental climate (6.4) and Eastern Europe (5.7) are ranked last from the aspect of average ranking points (Figures 4 and 5).

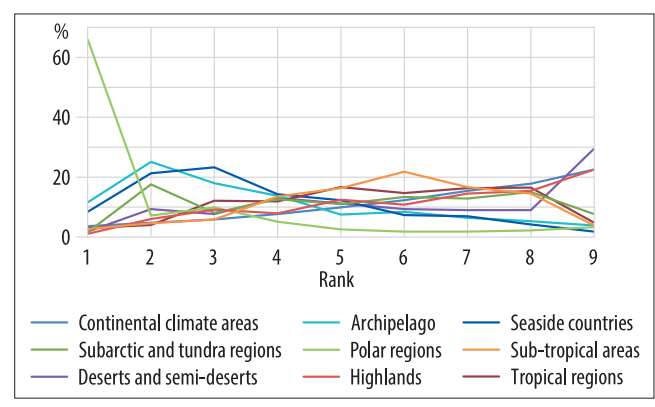

Fig. 4. Ranking of geographic-climatic regions from the point of view of their exposedness to climate change

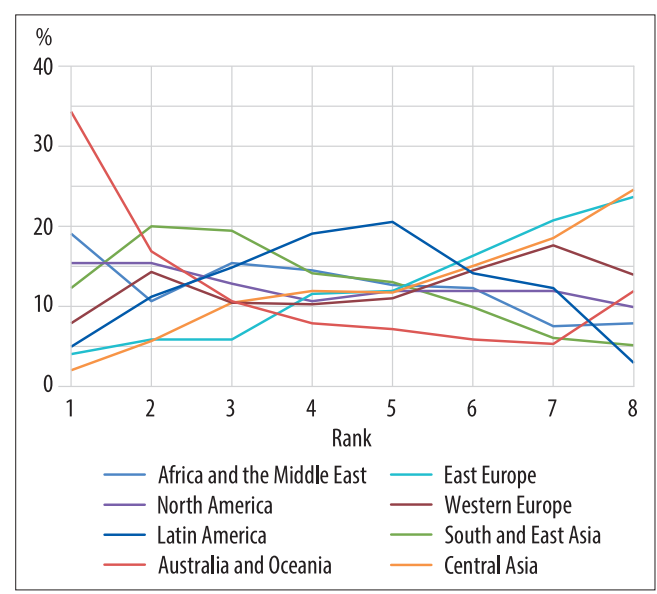

Fig. 5. Ranking of continental regions from the point of view of their exposedness to climate change

\section{The causes of climate change and the responsibility for action}

The first approach led us to the conclusion that more than half of the respondents (54\%) thinks that consumer society is responsible for climate change. This was followed by globalization $(20 \%)$, failure of environmental policies, and the progress of science and technology. From a rather sectoral approach, industry and the industrial revolution were ranked first (34\%), followed by the change in the land use and the reduction natural habi-

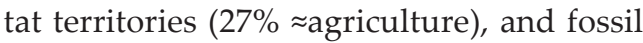
fuel based energy production (26\%). Transport and oil-industry were chosen by $6-6$ per cent of the respondents. (Compared to international data we see that industry is over-, transport is underestimated here.) However, if we create an aggregate score from the votes cast for fossil fuel based energy production and the companies interested in the oil industry, their share in responsibility is almost 33 per cent. A third approach offered the possibility to choose between developed and developing countries: two-thirds of respondents cited the responsibility of the former, while one-third were for that of the latter. However, the respondents were presumably unclear about the group to which Hungary belongs.

Our next question was: 'In your opinion, which entity is primarily responsible for the solving of problems arising from climate change?' We applied three different approaches here as well. According to the results, respondents would shift the responsibility to developed countries, economy and politics. Regarding the latter, international negotiations turned out to be more critical than national governments, but in between the two, there is the opinion considering individuals as key factors. BARANYAI, N. and VARJú, V. (2015) came to a different conclusion: in response to their question, which was similar to ours, science ranked first; however, they included the similar options into one question and used the Liker scale for evaluation.

When we involved the cartoons into the examination, we got a bit more complex view of the problem of perception (Table 1). Those 


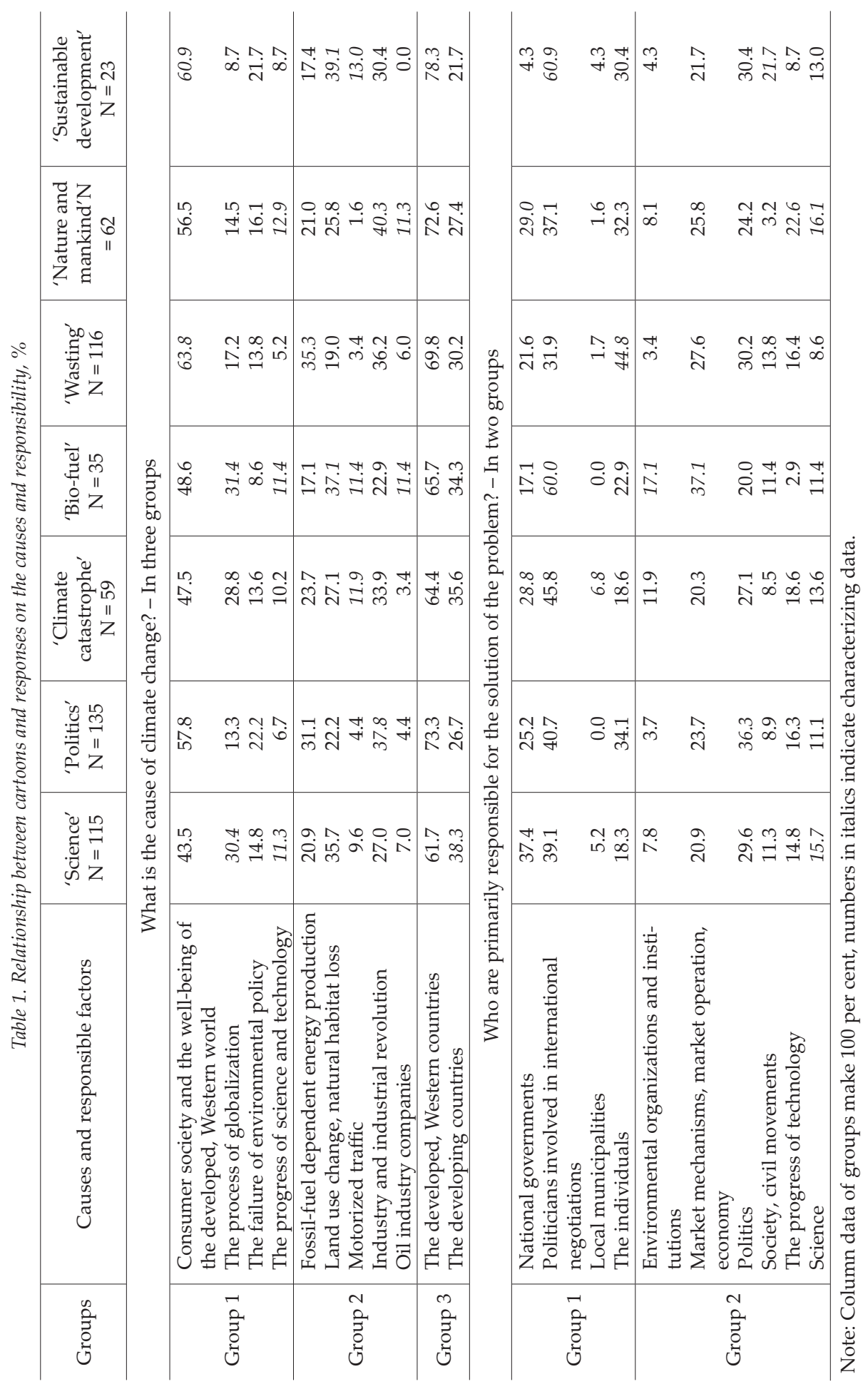


respondents who chose the picture implying the role and duties of science tended to think that science and technological progress are the reasons behind and are responsible for the solution of climate change. Nevertheless, even more surprisingly, they were represented in the highest rate among those who identified the developing countries as the cause of the problem. A considerable proportion of students chose this cartoon.

Those respondents (mainly people of tertiary-level education living in Budapest working as white-collar executives) who decided to select the politics-related picture marked the failure of environmental policy as the reason for the problems and (accordingly) politics as the key to problem solving. Those who blame industry and traffic for climate change chose the cartoon 'climate catastrophe in the desert,' a decision that is traceable to the basic antagonism between the environment and humanity. On the other hand, a significant number of these respondents marked national governments and local municipalities as key factors to finding a solution for a phenomenon that has no such clean-cut explanation.

Respondents identified technological progress and science, land use changes, traffic, and oil companies as the main causes of climate change in the cartoon concerning the problems associated with biofuels. This cartoon indirectly visualizes the conflict between developed and developing countries and the choices the respondents made properly fit into the visual and contextual world of this cartoon. The respondents who chose this cartoon emphasized the role of international politics, environmental organizations, and the market in problem solving. A higher number of older respondents (those above 60 years) chose this cartoon.

The 'wasting' cartoon was the most popular among people who live in Budapest, have relatively lower salaries, and work in offices or in the trade industry. These respondents identified consumer society and fossil fuel based energy resources as the leading causes of climate change, while, in their opinion, the primary responsibility for solving this problem lies with individuals. The choice of the cartoon visualizing the battle between nature and humanity involved the determination of scientific and technological progress, industry and oil companies as leading causes, and national governments, science and technology as those responsible for finding a solution to climate change (students were overrepresented in this group).

The cartoon about sustainable development (though it was rarely chosen, was picked mainly by respondents of higher education level) also fits into the idea of consumer society. The failure of environmental policy, land use change, natural habitat loss, traffic and developed countries were identified as main cause, and international politics and non-governmental, civil movements were identified as key factors of solving the problem of climate change. In summary, we think cartoons were useful tools in the survey: they gave a proper synthesis of different readings of climate change from which conclusions regarding actions could be drawn as well (see details below).

\section{Concern, environmental awareness, action}

Hereunder we examine the factors influencing actions, the mode of action and correlations between the level of concern, pro-environmental thinking and climate scepticism. We used four indicators for these analyses. After having the indexes correlated, we first received medium and weak correlations: correlation coefficients between index of concern, NEP and scepticism were $0.50,-0.57$ and -0.53 . The correlation coefficients between the indicator of actions and the three mentioned factors were $0.24,0.31$ and -0.26 (as for scepticism, correlations were ordinarily negative). That is to say that there is a medium-level relation among concern about climate change, pro-environmental thinking, and scepticism, but these factors rarely explain the differences of action indicator values. Paralleled, the respondents who chose 
'wasting' and 'battle between nature and humanity' cartoons demonstrated a higher level of concern, pro-environmental thinking, and readiness to act.

As a further approach, we clustered the respondents depending on the rank they gave to climate change among environmental problems as well as on the level of their concern. In the former case, we observed the same correlations and trends as described hereinabove, while in the latter case the correlation between the higher level of concern and the higher level of willingness to act was more obvious. Nevertheless, there are no signs that would demonstrate a paralyzed condition (inability to act) at an outstanding level of concern; namely, we could not verify our preliminary assumption in this regard.

What factors influence the actions and the values of other indicators? With respect to gender, women are more active in the field of actions, and they are more inclined to concern (the same result: TÁRKI 2007; SEARLE, K. and Gow, K. 2010) than men; in parallel, they have a more developed environmental thinking, and they are less sceptic. The harmonic change in indicators is also traceable among the values of age groups: the youngest and the oldest respondents are the less concerned, the less active, the less environment-friendly and the most sceptic, which is quite understandable.

Nevertheless, the examined four dimensions are more influenced by the type/size of the settlement and the level of education. Regarding the former, the NEP index shows a U-shape; while in the latter case, higher education level entrained, to a certain extent, higher average values (the scores were lower regarding scepticism) (Figure 6. - cf. BARANYAI, N. and VARJú, V. 2015).

Furthermore, we should mention the fact of living in a 'standard family model' (parents with kids) also seemed to have determinant power on the above-mentioned indicators. We could not demonstrate an obvious correlation between the indicators and the income per capita: the respondents in the second and fifth income clusters were the most concerned and the readiest to act. Neither could we identify a correlation between the indicators and labour market clusters: respondents employed in executive and white collar jobs, the large- and medium-size entrepreneurs, qualified office workers, trade industry employees and service providers were more typified by stronger concerns, a higher level of pro-environmental thinking and readiness to act, and less climate scepticism. Furthermore, it is a valuable sign that the index of concern and the index of activity was the highest among those respondents, who chose the cartoons 'waste' and 'battle between nature and humanity', and climate scepticism was the lowest among those who chose the cartoon visualizing the climate catastrophe.

Certain correlations in the fields of experience and responsibility seem to be quite obvious. Those who have direct knowledge of the problem are more concerned, more aware of environmental issues, less sceptic, and more ready to act; the same applies to those who identified the individual people as responsible for solving climate change. The midline is more or less represented by those respondents (diverting, however, downwards from the median in each case) who considered climate change as a factor influencing the past and the future as well. That is to say, the choice of the above answer also showed a certain level of scepticism in the sample. We also examined the daily logs of extreme weather events to check if those persons who filled out the questionnaire after such an extremity (within a one-week period) are more concerned about climate change or not. According to the results, there was no sign of any evidence (except that on the level of average values); however, on this scale, at least the direction of the correlation was the expected.

We examined the place of residence of respondents also, both in the relation of experience and the above four indicators. As for the direct experience of climate change, the average scores of respondents from Northern Hungary (Észak-Magyarország), Rim of the Alps (Alpokalja), and Budapest were the highest (they directly experience climate change). 

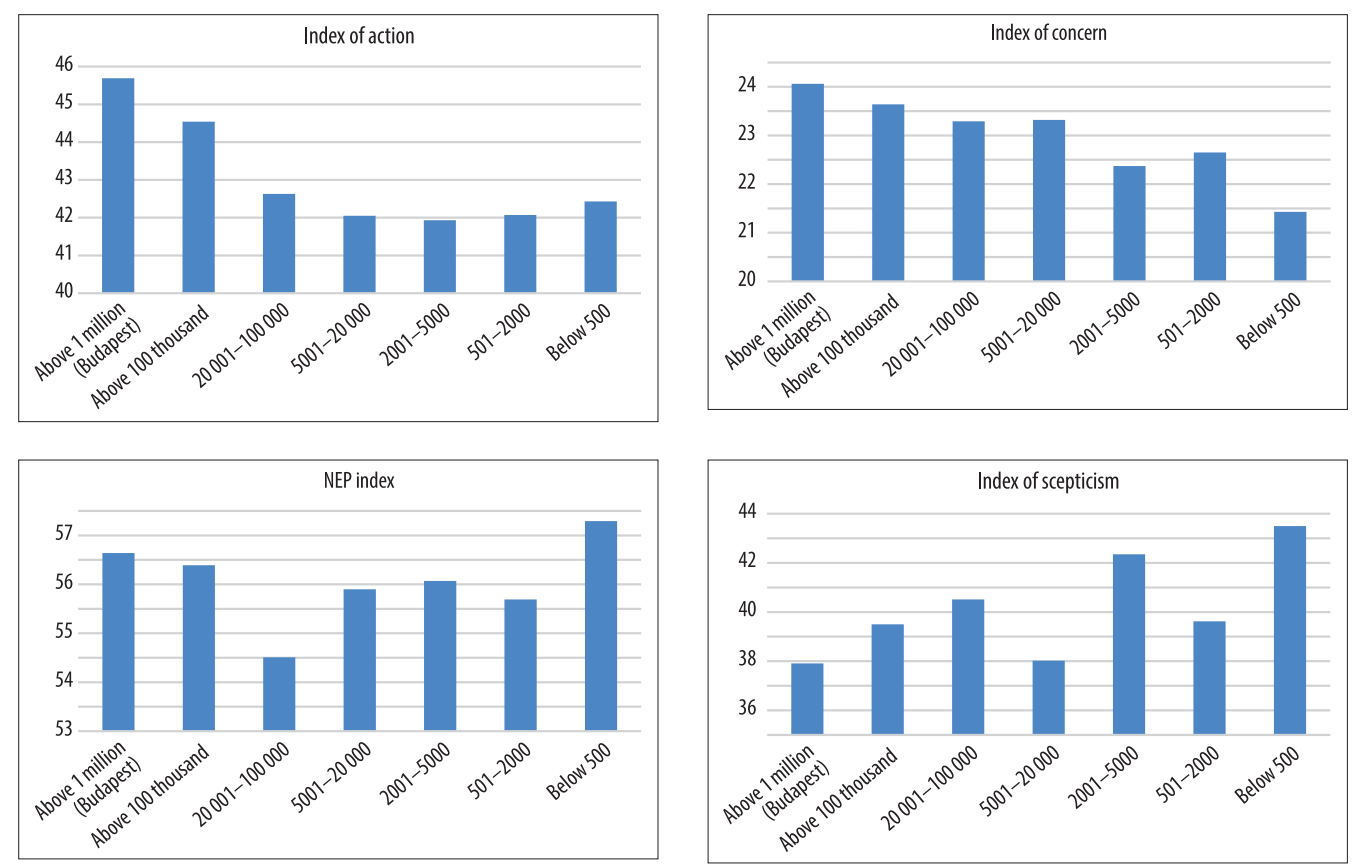

Fig. 6. Correlations between the category of settlement size and the four dimensions

This result contradicts our preliminary assumption: we expected a higher level of sensitivity in the region of the Great Hungarian Plain (Alföld). This finding suggests that direct experience is a stronger influencing factor in areas where people are unaccustomed to extremities. However, this is only one segment of correlations within the four examined dimensions. The index of concern reflects more or less the same results as the above correlation, but concerning the other indicators, Rim of the Alps provides the only outstanding scores while Great Hungarian Plain and Little Plain (Kisalföld) regions are presented more significantly instead of Northern Hungary.

\section{Summary and conclusions}

A core conclusion of our examinations is that climate change is a very complex issue with several possibilities of interpreta- tion and differentiated understanding: the topic divides people. This is the reason for the argument that climate change is not the proper issue to activate people (STOKNES, P.E. 2014) We offered several approaches in our study, but some of our questions remained open or were only partially verified. Our results reflect a moderate correlation between concerns and thoughts about climate change (pro-environmental thinking and climate scepticism), and a significantly weaker one between concerns and the intensity and consciousness of our actions. This is because the latter are more exposed to the influence of many other factors like settlement type, education level, gender, age, life values, or casual attributions in relation to climate change.

Another valuable result of the study is the demonstration that most of the respondents evaluated climate change as a phenomenon that is near in time, but geographically remote (cf. Hulme, M. 2008; Stoknes, P.E. 2014). This is a clear indication of cognitive 
conceptualization and problems with the localization of climate change in communication. The answers we received to our questionnaire also verified the existence of climate scepticism in Hungarian society, beyond temporality and geography it is also a fact that should be taken into consideration in the course of climate communication planning. Furthermore, we managed to identify several different clusters of respondents based on visualization of the problem, which verifies the thesis that the target group should always be considered carefully in communication projects.

Acknowledgements: The research was supported by the VKSZ_12-1-2013-0034 Agrárklíma.2 project.

\section{REFERENCES}

Akerlof, K., Maibach, E.W., Fitzgerald, D., Cedeno, A.Y. and Neuman, A. 2013. Do people "personally experience" global warming, and if so how, and does it matter? Global Environmental Change 23. 81-91.

AnTAL, Z.L. 2015. Klímaparadoxonok (Climate paradoxons). Budapest, L'Harmattan Kiadó.

Bajmóczy, P., Boros, L., Csatári, B., Dudás, R., Farkas, J.Zs., Juray, T., Kovács, Z. and PÁL, V. 2012. Managing the socio-economic consequences of the climate change. In Review of climate change research program at the University of Szeged. Eds.: RAKONCZAI, J. and LadÁNYI, Zs., Szeged, University of Szeged, Institute of Geography and Geology, 105-120.

BaranYai, N. and Varuú, V. 2015. A lakosság klímaváltozással kapcsolatos attitüdjének empirikus vizsgálata (Empirical study of citizens' attitude towards climate change). In Klímaváltozás - társadalom - gazdaság. Hosszú távú területi folyamatokés trendek Magyarországon. Eds.: CzIRFusz, M., HoyK, E. and Suvák, A., Pécs, Publikon Kiadó, 257-284.

Bartholy, J., Pongrácz, R. and Pieczka, I. 2014. How the climate will change in this century? Hungarian Geographical Bulletin 63. (1): 55-67.

BERECZKI, B.H. 2012. A klímaváltozás médiadiskurzusai (Media-discourses of climate change). Korunk 23. (2): 14-21.

Bobvos, J., Málnási, T., Rudnai, T., Cserbik, D. and PÁLDY, A. 2017. The effect of climate change on heatrelated excess mortality in Hungary at different area levels. Időjárás 121. (1): 43-62.

Brace, C. and Georghegan, H. 2010. Human geographies of climate change: Landscape, temporality and lay knowledges. Progress in Human Geography 35. (3): 284-302.
Broomell, S.B., Budescu, D.V. and Por, H-H. 2015. Personal experience with climate change predicts intentions to act. Global Environmental Change 32. 67-73.

Brulle, R.J., Carmichael, J. and Jenkins, J.C. 2012. Shifting public opinion on climate change: an empirical assessment of factors influencing concern over climate change in the U.S., 2002-2010. Climatic Change 114. (2): 169-188.

Corner, A., Whitmarsh, L. and Xenias, D. 2012. Uncertainty, scepticism and attitudes towards climate change: biased assimilation and attitude polarisation. Climatic Change 114. (3-4): 463-478.

Demeritt, D. 2001. Geographical work at the boundaries of climate change. Annals of the Association of American Geographers 91. (2): 307-337.

DonNer, S.D. 2011. Making the climate a part of the human world. Bulletin of the American Meteorological Society 92. 1297-1302.

Dunlap, R.E. and McCright, A.M. 2011. Organized climate change denial. In Oxford Handbook of Climate Change and Society. Eds.: Schlosberg, D., Dryzek, J. and NorgaArd, R., Cambridge, Oxford University Press, 144-160.

Dunlap, R.E. and van Liere, K.D. 1978. The „New Environmental Paradigm" A Proposed Measuring Instrument and Preliminary Results. Journal of Environmental Education 9. 10-19.

Dunlap, R.E., van Liere, K.D., Mertig, A.G. and JoNES, R.E. 2000. Measuring endorsement of the new ecological paradigm: a revised NEP scale. Journal of Social Issues 56. (3): 425-442.

Egan, P.J. and Mullin, M. 2012. Turning Personal Experience into Political Attitudes: The Effect of Local Weather on Americans' Perceptions about Global Warming. Journal of Politics 74. (3): 796-809.

FARKas, J.Zs., Hoyk, E. and RaKonczai, J. 2017. Geographical analysis of climate vulnerability at a regional scale: the case of the Southern Great Plain in Hungary. Hungarian Geographical Bulletin 66. (2): 129-144.

FARMer, G.T. and СоOK, J. 2013. Understanding Climate Change Denial. In Climate Change Science: A Modern Synthesis. Dordrecht, Springer, 445-466.

ForMÁDI, K. 2013. A klímaváltozás, mint kockázat érzékelése és a megoldásával kapcsolatos attitüdök szakirodalmi vizsgálata (Literature review of climate change: perception of risk and attitudes of solution). Iskolakultúra 12. 49-58.

Hamilton, L.C. and Stampone, M.D. 2013. Blowin' in the Wind: Short-Term Weather and Belief in Anthropogenic Climate Change. Weather, Climate and Society 5. 112-119.

Hulme, M. 2008. Geographical work at the boundaries of climate change. Transactions of the Institute of British Geographers 33. 5-11.

Hulme, M. 2009. Why we disagree about climate change? Understanding controversy, inaction and opportunity. Cambridge, Cambridge University Press. 
Hulme, M. 2014. Attributing weather extremes to 'climate change': A review. Progress in Physical Geography 38. (4): 499-511.

JANкó, F. 2015. Éghajlatváltozással kapcsolatos tudás a világháló magyar részén (Climate change knowledge on the Hungarian web). Tér és Társadalom 29. (2): 67-89.

Jankó, F., Móricz, N. and Papp-Vancsó, J. 2010. Klímaváltozás: tudományos viták és a társadalomföldrajz feladatai (Climate change: controversies in science and the objectives of human geography). Földrajzi Közlemények 134. (4): 405-418.

Jankó, F., Móricz, N. and Papp-VAncsó, J. 2011. Klímaváltozás: diskurzusok a katasztrófától a kételkedésig (Climate change: discourses from catastrophe to scepticism). Földrajzi Közlemények 135. (1): 3-16.

Kajner, P., Czira, T., Selmeczi, P. and Sütő, A. 2017. National Adaptation Geo-information System in climate. Időjárás 121. (4): 345-370.

Király, G., Czirfusz, M., Koós, B., Tagai, G. and Uzzoli, A. 2017. Population projection for Hungary and its relation with climate change. Europa XXI 32. 5-19.

Kőszegi, M., Bottlik, Zs., Telbisz, T. and Mari, L. 2015. Human-environment relationships in modern and postmodern geography. Hungarian Geographical Bulletin 64. (2): 87-99.

Lorenzoni, I. and Pidgeon, N.F. 2006. Public views on climate change: European and USA perspectives. Climatic Change 77. 73-95.

MANzo, K. 2010. Imaging vulnerability: the iconography of climate change. Area 42. 96-107.

Manzo, K. 2012. Earthworks: The geopolitical visions of climate change cartoons. Political Geography 31. 481-494.

Mesterházy, I., Mészáros, R. and Pongrácz, R. 2014. The effects of climate change on grape production in Hungary. Időjárás 118. (3): 193-206.

Moser, S.C. 2010. Communicating climate change: history, challenges, process and future directions. WIREs Climate Change 1. 31-53.

Mosoni-Fried, J., PÁlinkó, É. and Stefán, E. 2008. Klímaváltozás a közvélemény-kutatások tükrében (Climate change in public opinion polls). Klíma-21 füzetek 49. 45-58.

Myers, T.A., Maibach, E.W, Roser-Renouf, C., Akerlof, K. and Leiserowitz, A.A. 2013. The relationship between personal experience and belief in the reality of global warming. Nature Climate Change 3. 343-347.

Nerlich, B., Koteyko, N. and Brown, B. 2010. Theory and language of climate change communication. WIREs Climate Change 1. (1): 91-110.
Salamin, G., Kohán, Z., Dobozi, E. and Péti, M. 2011. Climate-friendly cities: a handbook on the tasks and possibilities of European cities in relation to climate change. Budapest, Ministry of Interior - VÁTI.

SchÄFER, M.S. 2012. Online communication on climate change and climate politics: a literature review. WIRES Climate Change 3. (6): 527-543.

SeArle, K. and Gow, K. 2010. Do concerns about climate change lead to distress? International Journal of Climate Change Strategies and Management 2. (4): 362-379.

Stoknes, P.E. 2014. Rethinking climate communications and the "psychological climate paradox". Energy Research \& Social Science 1. 161-170.

Szirmai, V., Molnár, B., Szépvölgyi, Á., SChuchmann, J. and VÁrADI, Zs. 2008. A klímaváltozás térbel hatásai a budapesti társadalomban (Regional effects of climate change in the society of Budapest). Klíma-21 füzetek 54. 51-71.

TÁRKI 2007. Klímaváltozás a nyilvánosságban (Climate change in public discourse). Társadalmi Klíma Riport 1. Budapest, TÁRKI Image Factory. http:// www.tarki.hu/adatbank-h/kutjel/pdf/b017.pdf Accessed: 11.01. 2017.

TNS 2009. Europeans' attitudes towards climate change. Special Eurobarometer 313. TNS Opinion \& Social, European Parliament and European Commission. https://ec.europa.eu/public_opinion/archives/ebs/ ebs_313_en.pdf. Accessed: 11.12. 2017.

TNS 2011. Climate change. Special Eurobarometer 372. TNS Opinion \& Social, European Commission. https:/ec.europa.eu/public_opinion/archives/ebs/ ebs_372_en.pdf. Accessed: 11.12. 2017.

TNS 2014. Climate change. Special Eurobarometer 409. TNS Opinion \& Social, European Commission. https://ec.europa.eu/public_opinion/archives/ebs/ ebs_409_en.pdf. Accessed: 11.12. 2017.

TNS 2017. Climate change. Special Eurobarometer 459. TNS Opinion \& Social, European Commission https:/ec.europa.eu/clima/sites/clima/files/support/ docs/report_2017_en.pdf. Accessed: 11.12. 2017.

Weber, E.U. and Stern, P.C. 2011. Public Understanding of Climate Change in the United States. American Psychologist 66. (4): 315-328.

Whitmarsh, L. 2011. Scepticism and uncertainty about climate change: dimensions, determinants and change over time. Global Environmental Change 21. 690-700. 
